\title{
PERTUMBUHAN TANAMAN KACANG PINTO (Arachis pintoi) YANG DIBERI BERBAGAI JENIS DAN DOSIS PUPUK ANORGANIK DAN ORGANIK
}

\author{
RONI, N. G. K. DAN S. A. LINDAWATI \\ Fakultas Peternakan Universitas Udayana \\ e-mail: gustironi@unud.ac.id
}

\begin{abstract}
ABSTRAK
Penelitian ini bertujuan untuk mengkaji pertumbuhan tanaman kacang pinto (Arachis pintoi) yang diberi berbagai jenis dan dosis pupuk anorganik dan organik serta mendapatkan level terbaik berbagai jenis pupuk dalam meningkatkan produktivitas tanaman kacang pinto. Penelitian menggunakan rancangan acak lengkap pola faktorial dua faktor yaitu Faktor pertamajenis pupuk ( $\mathrm{A}=$ Anorganik; $\mathrm{OP}=$ Organik Pabrik; $\mathrm{BO}=$ Bioorganik; BS= Biosluri), dan faktor kedua dosis pupuk (Do=tanpa Pupuk; D1= $100 \mathrm{~kg} \mathrm{Nha}^{-1}$; D2= $200 \mathrm{~kg} \mathrm{~N} \mathrm{ha}^{-1}$; dan D3= $300 \mathrm{~kg} \mathrm{Nha}^{-1}$ ). Terdapat 16 kombinasi perlakuan, diulang 3 kali sehingga terdapat 48 unit percobaan. Peubah yang diamati meliputi panjang tanaman, jumlah daun, jumlah cabang, diameter batang, berat kering daun, berat kering batang, berat kering total hijauan,luas daun per pot, dan nisbah berat kering daun/batang. Hasil penelitian menunjukkan bahwa tidak terjadi interaksi antara jenis dengan dosis pupuk, semua jenis pupuk organik menghasilkan pertumbuhan tanaman kacang pinto (Arachis pintoi) yang cenderung lebih tinggi dibandingkan pupuk anorganik, dosis pupuk D1 dan D2 cenderung meningkatkan, sedangkan dosis D3 cenderung menurunkan pertumbuhan tanaman kacang pinto. Berdasarkan hasil penelitian dapat disimpulkan bahwa tidak terjadi interaksi antara jenis dengan dosis pupuk, semua jenis pupuk organik menghasilkan pertumbuhan tanaman kacang pinto (Arachis pintoi) yang cenderung lebih baik dibandingkan dengan pupuk anorganik, dan dosis pupuk 120-200 kg $\mathrm{Nha}^{-1}$ cenderung optimal dalam mempengaruhi pertumbuhan tanaman kacang pinto.
\end{abstract}

Kata kunci: Arachis pintoi, dosis pupuk, pupuk organik, pupuk anorganik

\section{GROWTH OF ARACHIS PINTOI FORAGE WHICH IS GIVEN VARIOUS OF TYPES AND DOSAGE OF ANORGANIC AND ORGANIC FERTILIZER}

\begin{abstract}
This study aims to assess the growth of Arachis pintoi forage which is given various types and doses of fertilizer and get the best level of various types of fertilizers in increasing the growth of Arachis pintoi plant. This research used to a completed randomized design with factorial pattern of two factors, the first factor is the type of fertilizer ( $\mathrm{A}=$ Inorganic; $\mathrm{OP}=$ Organic Factory; $\mathrm{BO}=$ Bioorganic; $\mathrm{BS}=$ Biosluri), and the second factor is the dose of fertilizer (Do = without fertilizer; D1 $=100 \mathrm{~kg} \mathrm{Nha}^{-1} ; \mathrm{D} 2=200 \mathrm{~kg} \mathrm{Nha}^{-1}$; and D3 $=300 \mathrm{~kg} \mathrm{Nha}^{-1}$ ). There were 16 treatment combinations and each treatment was repeated 3 times, so consist of 48 experimental units. Variables observed included plant length, number of leaves, number of branches, stem diameter, leaf dry weight, stem dry weight, dry weight of total forage, leaf area per pot, and leaf/stem dry weight ratio. The results showed that there was no interaction between types and doses of fertilizer, all types of organic fertilizer produce growth of Arachis pintoi which tends to be higher than inorganic fertilizer, D1 and D2 fertilizer doses tend to increase, while D3 doses tend to decrease the growth of the pinto bean forage. Based on the results of the study, it can be concluded that there is no interaction between types and fertilizer dosage, all types of organic fertilizers produced plant growth of Arachis pintoi which tends to be higher than inorganic fertilizers, and fertilizer doses of $120-200 \mathrm{~kg} \mathrm{~N} \mathrm{ha}^{-1}$ tend to be optimal in influencing the growth of Arachis pintoi forage.
\end{abstract}

Key words: Arachis pintoi, dosage of fertilizer, organic fertilizer, anorganic fertilizer 


\section{PENDAHULUAN}

Hijauan pakan merupakan salah satu faktor utama yang berperan dalam mendukung produktivitas ternak. Dalam ransum ruminansia, porsi hijauan pakan mencapai $40-80 \%$ dari total bahan kering ransum atau sekitar 1,5-3\% dari bobot hidup ternak. Secara nutrisi hijauan pakan merupakan sumber serat, bahkan hijauan pakan asal leguminosa menjadi suplementasi mineral dan protein murah bagi ternak ruminansia. Hijauan pakan berperan sebagai faktor penggertak agar rumen sapi dapat berfungsi normal (Abdullah et al., 2005).

Kacang pinto (Arachis pintoi)merupakan salah satu tanaman pakan yang sangat disukai oleh ternak (palatable), memiliki nilai nutrisi yang tinggi dan memiliki beberapa fungsi yaitu sebagai pakan baik untuk ruminansia maupun non ruminansia, meningkatkan kesuburan tanah, mencegah erosi, serta menjadi tanaman hias (Ferguson dan Loch, 1999). Pemupukan dengan pupuk kandang sapi dosis 20 tonha $^{-1}$ dapat meningkatkan produksi kacang pinto (Roni et al., 2017). Kacang pinto juga dilaporkan memiliki produktivitas yang tinggi pada naungan 55\% dibandingkan tanpa naungan (Sirait, 2005). Hal ini memiliki arti penting terkait permasalahan penyediaan hijauan yaitu kurangnya lahan khusus untuk hijauan pakan.

Panen hijauan pakan berarti pengambilan unsurunsur hara sehingga jumlahnya di dalam tanah menurun. Pemupukan merupakan salah satu cara untuk meningkatkan jumlah hara yang tersedia di dalam tanah. Penggunaan pupuk kimia (anorganik) secara terus menerus dalam jangka waktu lama dapat menyebabkan tercemarnya kondisi lingkungan, juga dapat mengubah sifat fisik tanah menjadi keras (Sugito, 1999), karena penggunaan pupuk kimia secara terus-menerus dalam jumlah banyak merupakan salah satu penyebab degradasi lahan (Kartini, 2000). Pada tanaman gamal dan indigofera, pupuk organik dan bioorganik produksi masyarakat mampu menghasilkan respons yang sama dengan pupuk organik produksi pabrik pupuk dan pupuk anorganik NPK (Roni dan Lindawati, 2018). Untuk itu perlu digali informasi mengenai aplikasi jenis-jenis pupuk yang selain menjadi sumber hara untuk tanaman juga ramah lingkungan, dapat mengurangi dan mencegah terjadinya degradasi tanah. Informasi mengenai aplikasi berbagai jenis dan dosis pupuk pada tanaman pakan kacang pinto (Arachis pintoi) masih terbatas sehingga penting untuk dilakukan penelitian.

\section{MATERI DAN METODE}

Penelitian dilaksanakan di rumah kaca Laboratorium Tumbuhan Pakan, Fakultas Perternakan, Universitas Udayana di Stasiun Penelitian Fakultas Peternakan jalan raya Sesetan gang Markisa, Denpasar Selatan selama enam bulan. Bahan yang digunakan berupa tanah, air, pupuk, dan bibit tanaman. Peralatan yang digunakan adalah ayakan kawat, pot plastik, penggaris, pisau, gunting, kantong kertas, oven, timbangan kue, timbangan digital dan portable leaf area meter.

\section{Persiapan Media Tanam}

Sebanyak $4 \mathrm{~kg}$ tanah kering udara yang lolos ayakan dengan lubang berdiameter $4 \mathrm{~mm}$ dimasukkan ke dalam pot plastik berdiameter $20 \mathrm{~cm}$ dengan kapasitas $5 \mathrm{~kg}$, kemudian tiap-tiap pot diberi pupuk sesuai perlakuan, dan selanjutnya diberi label.

\section{Pemberian Pupuk}

Pupuk organik diberikan sebelum penanaman bibit sesuai perlakuan dengan cara menaburkan di permukaan tanah dan mencampur dengan tanah hingga homogen. Pupuk anorganik (NPK) diberikan setelah tanaman berumur 1 minggu setelah tanam..

\section{Penanaman Bibit}

Stek batang kacang pinto yang digunakan terlebih dahulu ditanam di tempat persemaian, setelah stek tumbuh dipilih yang tumbuhnya seragam untuk kemudian ditanam masing-masing 1 bibit pada setiap pot.

\section{Pemeliharaan dan pengamatan pertumbuhan}

Pemeliharaan yang dilakukan adalah penyiraman setiap hari pada volume 100\% kapasitas lapang, serta pengendalian hama dan penyakit bila diperlukan. Pengamatan terhadap peubah pertumbuhan dilakukan setiap minggu sekali mulai tanaman berumur dua minggu setelah tanam.

\section{Pemanenan}

Panen dilakukan pada saat tanaman berumur 9 minggu setelah tanam dengan cara memotong tanaman di atas permukaan tanah kemudian memisahkan antara batang dan daun. Setiap bagian-bagian tersebut ditimbang untuk mengetahui berat segarnya, untuk selanjutnya dikeringkan untuk mendapatkan berat keringnya.

\section{Rancangan Percobaan}

Penelitian ini menggunakan rancangan acak lengkap pola faktorial yang terdiri atas 2 faktor yaitu :

Faktor pertama adalah jenis pupuk yaitu :

$$
\mathrm{A}=\text { Pupuk anorganik } \mathrm{BO}=\underset{\text { bioorganik }}{\text { Pupuk }}
$$

$\mathrm{OP}=$ Pupuk organik pabrik $\mathrm{BS}=$ Pupuk biosluri

Faktor kedua adalah dosis pupuk yaitu :
Do $=$ Tanpa pupuk
D2 $=200 \mathrm{~kg} \mathrm{~N}$ ha-1
D1 $=100 \mathrm{~kg} \mathrm{~N} \mathrm{ha}^{-1}$
D3 $=300 \mathrm{~kg} \mathrm{~N} \mathrm{ha}^{-1}$ 
Dari kedua faktor tersebut diperoleh 16 kombinasi perlakauan yaitu: $\mathrm{ADo}, \mathrm{AD} 1, \mathrm{AD} 2, \mathrm{AD} 3$, OPDo, OPD1, OPD2, OPD3, BODo, BOD1, BOD2, BOD3, BSDo, BSD2, BSD3, BSD4. Setiap kombinasi perlakuan diulang tiga kali, sehingga terdapat 48 unit percobaan.

\section{Analisis Data}

Data yang diperoleh dianalisis dengan analisis sidik ragam univarian (Program SPSS), dan apabila nilai rata-rata perlakuan menunjukkan perbedaan yang nyata $(\mathrm{P}<0.05)$, maka analisis dilanjutkan dengan uji jarak berganda dari Duncan pada taraf nyata 5\% (Steel dan Torrie, 1991).

\section{HASIL DAN PEMBAHASAN}

Tidak terjadi interaksi antara jenis dengan dosis pupuk terhadap produktivitas tanaman kacang pinto. Ini berarti antara jenis dan dosis pupuk bekerja sendirisendiri dalam mempengaruhi pertumbuhan, hasil hijauan dan karakteristik tumbuh tanaman kacang pinto (Arachis pintoi). Seperti halnya dijelaskan oleh Gomez dan Gomez (1995) bahwa dua faktor perlakuan dikatakan berinteraksi apabila pengaruh suatu faktor perlakuan berubah pada saat perubahan taraf faktor perlakuan lainnya. Bila pengaruh interaksi berbeda tidak nyata, maka disimpulkan bahwa diantara faktor-faktor perlakuan tersebut bertindak bebas atau pengaruhnya berdiri sendiri (Steel dan Torrie, 1991).
Tabel 1. menunjukkan bahwa semua jenis pupuk menghasilkan panjang tanaman, jumlah daun dan jumlah cabang yang berbeda tidak nyata $(\mathrm{P}>0,05)$, mengindikasikan bahwa tanaman kacang pinto memberikan respons yang sama terhadap semua jenis pupuk yang diberikan. Hasil penelitian ini sejalan dengan hasil penelitian Roni dan Lindawati (2018) yang melaporkan bahwa pupuk organik menghasilkan respons yang sama dengan pupuk anorganik pada tanaman gamal (Gliricidia sepium) dan indigofera (Indigofera zollingeriana).

Semua jenis pupuk organik menghasilkan panjang tanaman, jumlah daun, jumlah cabang (Tabel 1), luas daun per pot (Tabel 2) yang cenderung $(\mathrm{P}>0,05)$ lebih tinggi dan diameter batang (Tabel 2) yang nyata $(\mathrm{P}<0,05)$ lebih tinggi dibandingkan dengan pupuk anorganik. Hal ini mengindikasikan bahwa pemanfaatan pupuk organik mampu menggantikan pupuk anorganik terutama dalam meningkatkan produktivitas tanaman pakan kacang pinto. Selain berfungsi meningkatkan pertumbuhan tanaman, pupuk organik juga dapat menghindarkan tanah dari kerusakan baik fisik, kimia maupun biologi akibat penggunaan pupuk anorganik yang berlebihan dalam jangka waktu yang lama. Ini terjadi karena pupuk organik juga berperan sebagai sumber energi dan makanan mikroba tanah sehingga dapat meningkatkan aktivitas mikroba tersebut dalam penyediaan hara tanaman. Jadi penambahan bahan organik disamping sebagai sumber hara bagi tanaman,

Tabel 1. Pertumbuhan kacang pinto (Arachis pintoi) yang diberi berbagai jenis dan dosis pupuk anorganik dan organik

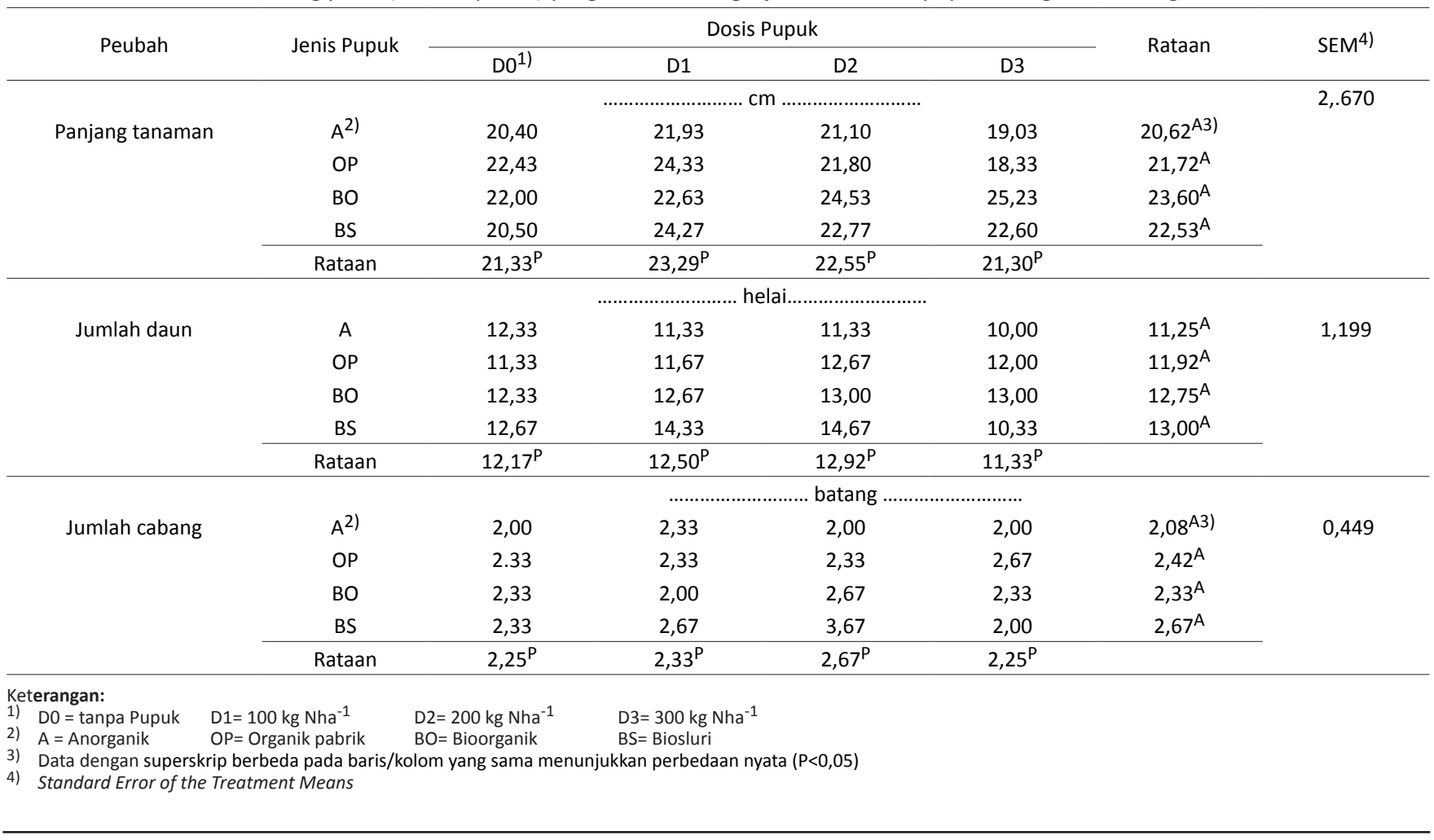


Tabel 2. Diameter batang dan luas daun per pot kacang pinto (Arachis pintoi) yang diberi berbagai jenis dan dosis pupuk anorganik dan organik

\begin{tabular}{|c|c|c|c|c|c|c|c|}
\hline \multirow{2}{*}{ Peubah } & \multirow{2}{*}{$\begin{array}{c}\text { Jenis } \\
\text { Pupuk }\end{array}$} & \multicolumn{4}{|c|}{ Dosis Pupuk } & \multirow{2}{*}{ Rataan } & \multirow{2}{*}{ SEM $^{4)}$} \\
\hline & & $\mathrm{DO}^{1)}$ & D1 & D2 & D3 & & \\
\hline \multirow{6}{*}{$\begin{array}{c}\text { Diameter } \\
\text { batang }\end{array}$} & \multicolumn{6}{|c|}{ 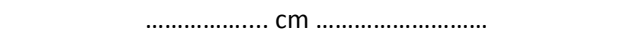 } & \multirow[t]{6}{*}{0,021} \\
\hline & $A$ & 0,37 & 0,35 & 0,38 & 0,35 & $0,36^{\mathrm{B}}$ & \\
\hline & OP & 0,41 & 0,44 & 0,42 & 0,40 & $0,42^{\mathrm{A}}$ & \\
\hline & $\mathrm{BO}$ & 0,42 & 0,41 & 0,41 & 0,41 & $0,41^{\mathrm{A}}$ & \\
\hline & BS & 0,41 & 0,40 & 0,42 & 0,37 & $0,40^{\mathrm{A}}$ & \\
\hline & Rataan & $0,40^{P}$ & $0,40^{P}$ & $0,41^{P}$ & $0,38^{P}$ & & \\
\hline \multirow{6}{*}{$\begin{array}{c}\text { Luas aun } \\
\text { per pot }\end{array}$} & \multicolumn{6}{|c|}{ 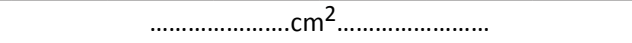 } & \multirow{6}{*}{$3^{113,64}$} \\
\hline & $A^{2)}$ & 636,12 & 634,97 & 645,90 & 469,21 & $596,55^{A 3}$ & \\
\hline & $\mathrm{OP}$ & 581,88 & 768,36 & 608,09 & 522,02 & $620,09^{A}$ & \\
\hline & BO & 735,30 & 731,81 & 729,04 & 832,85 & $757,25^{A}$ & \\
\hline & BS & 707,14 & 960,17 & 754,37 & 613,57 & $758,81^{A}$ & \\
\hline & Rataan & $665,11^{P}$ & $773,83^{P}$ & $684,35^{P}$ & $609,41^{P}$ & & \\
\hline \multicolumn{8}{|c|}{ Keterangan: } \\
\hline \multirow{2}{*}{\multicolumn{2}{|c|}{$\begin{array}{l}\text { 1) } \mathrm{DO}=\text { tanpa Pupuk } \\
\text { 2) } \mathrm{A}=\text { Anorganik }\end{array}$}} & \multirow{2}{*}{\multicolumn{2}{|c|}{$\begin{array}{l}\mathrm{D} 1=100 \mathrm{~kg} \mathrm{Nha}^{-1} \\
\mathrm{OP}=\text { Organik pabrik }\end{array}$}} & \multirow{2}{*}{\multicolumn{2}{|c|}{$\begin{array}{l}\mathrm{D} 2=200 \mathrm{~kg} \mathrm{Nha}^{-1} \\
\mathrm{BO}=\text { Bioorganik }\end{array}$}} & \multicolumn{2}{|c|}{$\mathrm{D} 3=300 \mathrm{~kg} \mathrm{Nha}^{-1}$} \\
\hline & & & & & & BS= Biosluri & \\
\hline \multicolumn{8}{|c|}{$\begin{array}{l}\text { 3) Data dengan superskrip berbeda pada baris/kolom yang sama menunjukkan perbe- } \\
\text { daan nyata }(P<0,05)\end{array}$} \\
\hline 4) Standar & Error f & the Treatm & ent Means & & & & \\
\hline
\end{tabular}

sekaligus sebagai sumber energi dan hara bagi mikroba (Simanungkalit et al., 2006).

Pada perlakuan dosis pupuk D1 dan D2 cenderung terjadi peningkatan $(\mathrm{P}>0,05)$ panjang tanaman, jumlah daun, jumlah cabang (Tabel 1, Gambar 1), diameter batang dan luas daun per pot (Tabel 2, Gambar 2) tanaman kacang pinto dibandingkan dengan dosis pupuk Do, tetapi cenderung terjadi penurunan $(\mathrm{P}>0,05)$ pada dosis pupuk D3. Hal ini mengindikasikan bahwa pemberian pupuk pada dosis D3 sudah mulai terjadi kelebihan pupuk yang justru berakibat pada penurunan hasil tanaman. Lingga dan Marsono (2007) menyatakan bahwa pemberian pupuk harus dilakukan secara tepat dan sesuai konsentrasi yang dianjurkan, karena pemberian pupuk yang berlebihan akan menyebabkan keracunan pada tanaman. Apabila proses memupuk ini tidak tepat dan sesuai konsentrasinya, maka hasil yang diperoleh tidak optimal. Harus ada sinkronisasi atau kesesuaian waktu ketersediaan unsur hara dan kebutuhan tanaman akan unsur hara (Myer et al., 1997).

Gambar 1. menunjukkan bahwa berdasarkan nilai rataan (R) semua jenis pupuk, peningkatan dosis pupuk dapat meningkatkan panjang tanaman secara kuadratik dengan persamaan $y=-0,00008 x^{2}+0.023 x+21.44$ dan dari persamaan tersebut diperoleh titik optimal pada dosis $144 \mathrm{~kg} \mathrm{~N}$ ha $^{-1}$ dengan panjang tanaman 23,093 $\mathrm{cm}$; jumlah daun secara kuadratik dengan persamaan $\mathrm{y}=-0,00005 \mathrm{x}^{2}+0.012 \mathrm{x}+12,06$ dan dari persamaan tersebut diperoleh titik optimal pada dosis $120 \mathrm{~kg} \mathrm{~N}$ $\mathrm{ha}^{-1}$ dengan jumlah daun 12,78 helai; jumlah cabang secara kuadratik dengan persamaan $\mathrm{y}=-0,00001 \mathrm{x}^{2}+$ $0.004 x+2,199$ dan dari persamaan tersebut diperoleh
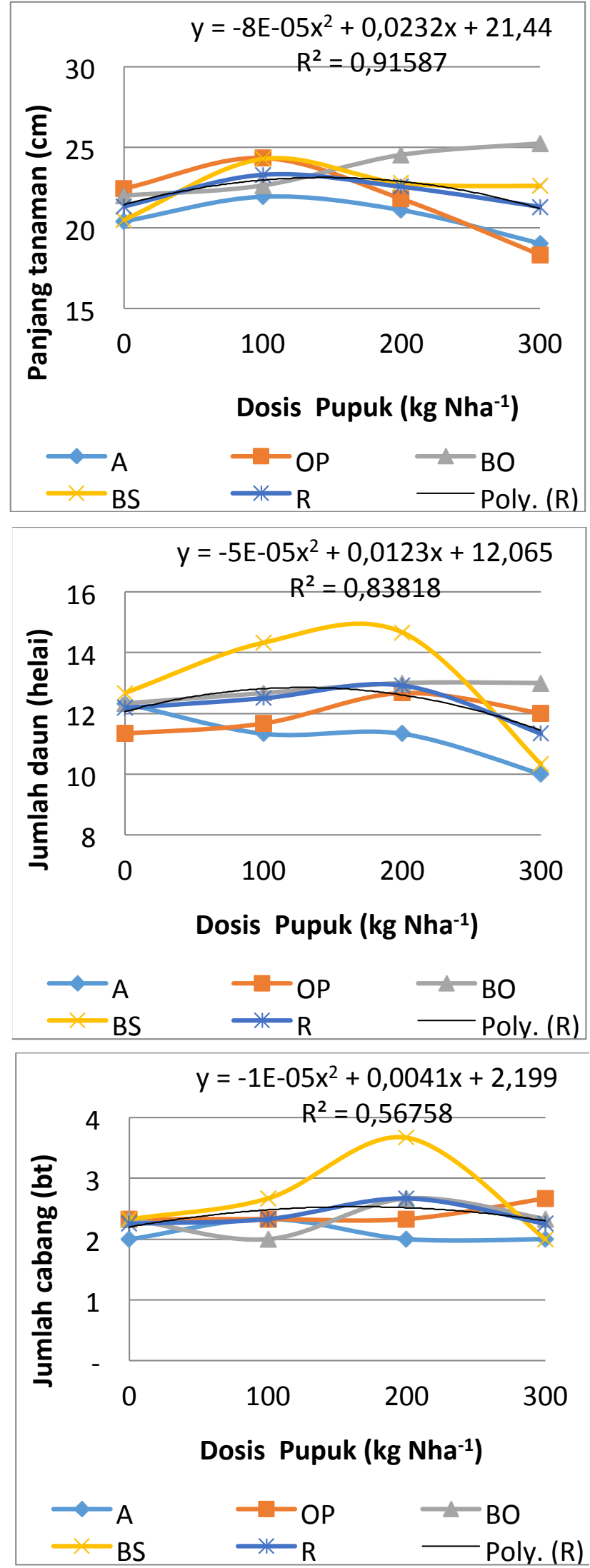

Gambar 1. Tinggi tanaman, jumlah daun dan jumlah cabang kacang pinto (Arachis pintoi)

A: anorganik, OP:organik pabrik, BO;bioorganik, BS: biosluri, R:rataan 

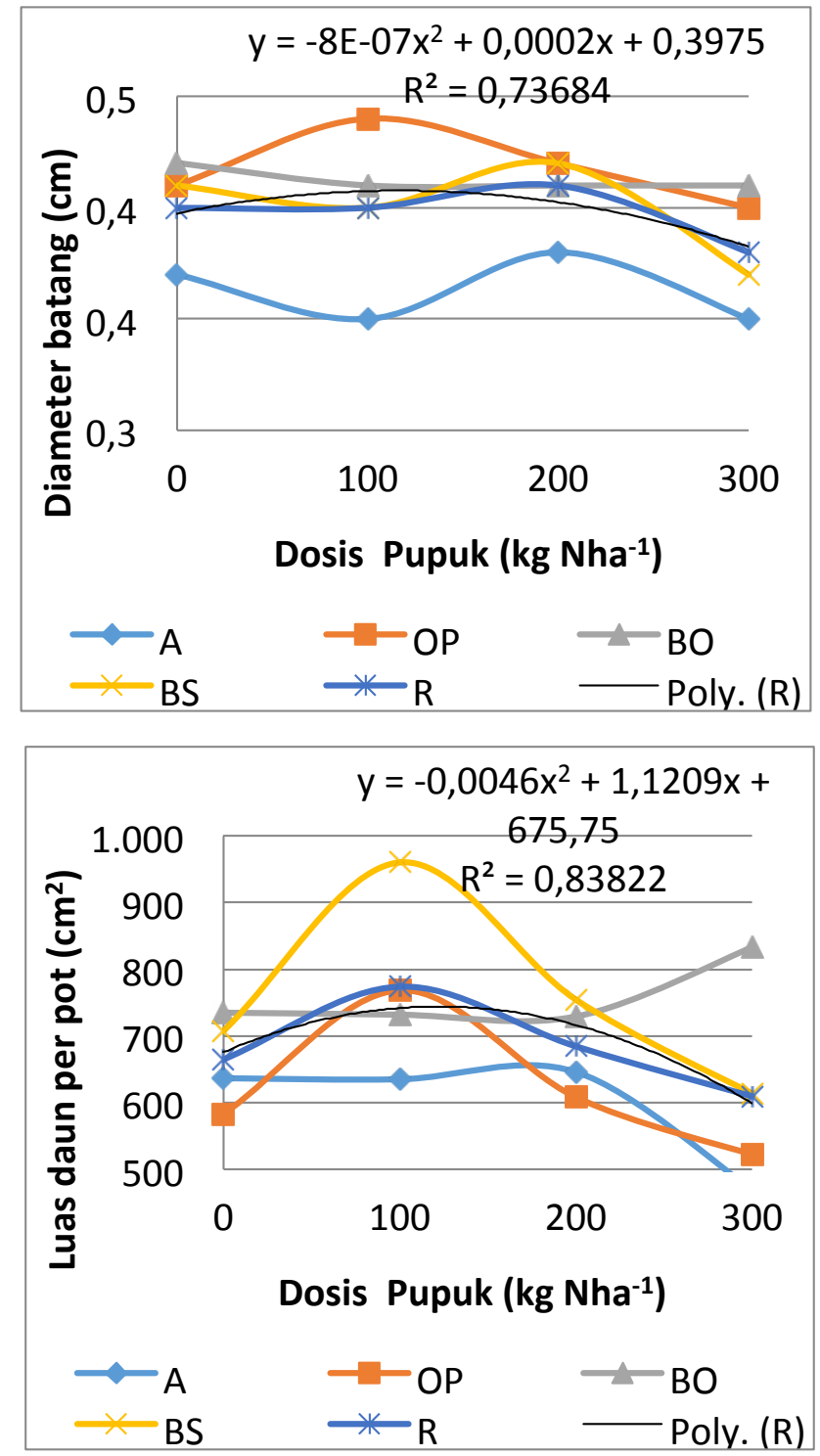

Gambar 2. Diameter batang dan luas daun per pot kacang pinto (Arachis pintoi)

A: anorganik, OP:organik pabrik, BO; bioorganik, BS: biosluri, R:rataan

titik optimal pada dosis $200 \mathrm{kgNha}^{-1}$ dengan jumlah daun 2,599 batang. Untuk luas daun per pot didapat persamaan $\mathrm{y}=-0,004 \mathrm{x}^{2}+1,120 \mathrm{x}+675,7$ dan dari persamaan tersebut diperoleh titik optimal pada dosis $140 \mathrm{kgNha}^{-1}$ dengan jumlah daun $754,1 \mathrm{~cm}^{2}$ (Gambar 2.).

Penurunan panjang tanaman, jumlah daun, jumlah cabang, diameter batang dan luas daun per pot pada dosis pupuk $300 \mathrm{~kg} \mathrm{Nha}^{-1}$ (D3) tidak terjadi pada perlakuan pupuk bioorganik (BO). Ini berarti indikasi kelebihan pupuk pada perlakuan pupuk BO belum terjadi sampai dengan dosis $300 \mathrm{~kg} \mathrm{~N} \mathrm{ha-1}$. Hasil penelitian ini sesuai dengan hasil penelitian Roni dan Lindawati (2019) yang mendapatkan bahwa penggunaan pupuk bioorganik dengan dosis 5 ton ha ${ }^{-1}$ sudah mampu meningkatkan produktivitas tanaman gamal dan indigofera dan sampai perlakuan dosis 30 ton $\mathrm{ha}^{-1}$ masih terjadi peningkatan produktivitas, berarti belum terindikasi adanya keracunan karena kelebihan dosis pupuk. Hal ini terjadi karena pupuk BO dihasilkan dengan memanfaatkan teknologi mikroba. Pupuk yang dihasilkan dengan memanfaatkan teknologi mikroba disebut sebagai pupuk bioorganik, mikroba akan tetap hidup dan aktif di dalam pupuk ketika pupuk tersebut diberikan di tanah, dan mikroba akan mengendalikan organisme patogen penyebab penyakit tanaman (Setiadi, 2012).

\section{SIMPULAN}

Berdasarkan hasil penelitian dapat disimpulkan bahwa tidak terjadi interaksi antara jenis dengan dosis pupuk, semua jenis pupuk organik menghasilkan pertumbuhan tanaman kacang pinto (Arachis pintoi) yang cenderung lebih tinggi dibandingkan dengan pupuk anorganik, dan dosis pupuk 120-200 kg N ha-1 cenderung optimal dalam mempengaruhi pertumbuhan tanaman kacang pinto.

\section{DAFTAR PUSTAKA}

Abdullah, L. Panca Dewi, M. H. K., Soedarmadi, H. 2005. Reposisi tanaman pakan dalam kurikulum fakultas peternakan. Prosiding Lokakarya Nasional Tanaman Pakan Ternak; Bogor, 16 September 2005. Pusat Penelitian dan Pengembangan Peternakan. Badan Penelitian dan Pengembangan Pertanian. Hlm 11-17.

Ferguson, J. E and D. S. Loch. 1999. Arachis pintoi in Australia and Latin America. In Loch DS and JE Ferguson, editor. Forage seed Production. Tropical and Subtropical Species Volume 2. Oxon.UK.CABI Publishing. hlm 427- 434.

Gomez, K. A. dan Gomez, A. A. 1995. Prosedur Statistik Untuk Penelitian Edisi Kedua. Jakarta:UI-Pres, hal :13-16

Kartini, N. L. 2000. Pertanian Organik Sebagai Pertanian Masa Depan. Prosiding Seminar Nasional Pengembangan Teknologi Pertanian Dalam Upaya Mendukung Ketahanan Pangan Nasional. Pusat Penelitian Dan Pengembangan Social Ekonomi Pertanian Bekerjasama Dengan Universitas Udayana Denpasar.

Lingga, P. dan Marsono. 2007. Petunjuk Penggunaan Pupuk. Penebar Swadaya. Jakarta.

Myers, R. J. K., C. A. Palm., E. Cuevas., I. V. N. Gunatileke and M. Bbrossard. 1997. The Syncronisation of Nutrient Mineralization and Plant Nutrient 
Demand. In Management of Tropical Soil Fertillity. Agronomy Journal 87:642-648.

Roni N. G. K., N. N. C. Kusumawati, N.M. Witariadi dan S.A. Lindawati. 2017. Produksi dan karakteristik kacang pinto yang diberi pupuk kandang sapi dan mikoriza. Pastura. Jurnal ilmu tumbuhan pakan. 6(2): 94-97. https://ojs.unud.ac.id/index.php/ pastura/article/view/45453/27563. Diakses tanggal 30 Oktober 2019.

Roni N. G. K. dan S. A. Lindawati. 2018. Respon tanaman gamal (Gliricidia sepium) dan indigofera (Indigofera zollingeriana) terhadap pemberian pupuk anorganik dan organik. Pastura. Jurnal ilmu tumbuhan pakan. 8(1): 33-38. https:// ojs.unud.ac.id/index.php/pastura/article/ view/45531/27639. Diakses tanggal 5 November 2019.

Roni N. G. K. dan S. A. Lindawati. 2019. Produktivitas tanaman gamal (Gliricidia sepium) dan indigofera (Indigofera zollingeriana) yang diberi berbagai dosis pupuk bioorganik. Pastura. Jurnal ilmu tumbuhan pakan. 8(2): 105-109. https://ojs.unud.ac.id/index. php/pastura/article/view/54842. Diakses tanggal 12 Oktober 2020.

Setiadi Y. 2012. Bio-organik sebagai bahan pembenah tanah. httpelti.fesprojects.net2012\%20Course\%2O
Mining\%2oReg\%2oIndonesiasetiadi_bio-organik. pdf. Diunduh2 Oktober 2018.

Simanungkalit R. D. M, D. A. Suriadikarta, R. Saraswati, D. Setyorini dan W. Hartatik. 2006. Pupuk Organik dan Pupuk Hayati.. Balai Besar Penelitian Dan Pengembangan Sumber Daya Lahan Pertanian. Badan Penelitian dan Pengembangan Pertanian. Jawa Barat.

Sirait, J., S. P. Ginting dan A. Tarigan. 2005. Karakterisasi morfologi dan produksi legume pada tiga taraf naungan di dua agroekosistem. Pros. Lokakarya Nasional tanaman Pakan.

Steel, R.G.D. and J.H. Torrie. 1991. Principles and Procedure of Statistics. McGraw Hill Book Co. Inc. New York.

Steel, R. G. D. dan R. A. Torrie. 1991. Prinsip dan Prosedur Statistka. Suatu Pendekatan Biometrik. Gramedia Pustaka Utama. Jakarta.

Sugito, Y., 1999, Ekologi Tanaman:Pengaruh Factor Lingkungan Terhadap Pertumbuhan Tanaman dan Beberapa aspeknya, UB Press. Malang.

Tilman, A. D., H. Harjadi, S. Reksohardiprodjo, S. Prawirokusumo dan S. Lebdosoekojo. 1991. Ilmu Makanan Ternak Dasar. Gadjah Mada Universitas Press, Yogyakarta. 